$11-1-2021$

\title{
Who Are Our Fans: An Application of Principal Component-Cluster Technique Analysis to Market Segmentation of College Football
}

\section{Fans}

\author{
DANIEL A. RASCHER \\ University of San Francisco, RASCHER@USFCA.EDU \\ Kenneth Cortsen \\ University College Nordjylland \\ Mark S. Nagel \\ University of South Carolina \\ Tiffany Richardson \\ Seattle University
}

Follow this and additional works at: https://trace.tennessee.edu/jasm

Part of the Marketing Commons, and the Sports Studies Commons

\section{Recommended Citation \\ RASCHER, DANIEL A.; Cortsen, Kenneth; Nagel, Mark S.; and Richardson, Tiffany (2021) "Who Are Our Fans: An Application of Principal Component-Cluster Technique Analysis to Market Segmentation of College Football Fans," Journal of Applied Sport Management: Vol. 13 : Iss. 1. \\ https://doi.org/10.7290/jasm130172 \\ Available at: https://trace.tennessee.edu/jasm/vol13/iss1/1}

This article is brought to you freely and openly by Volunteer, Open-access, Library-hosted Journals (VOL Journals), published in partnership with The University of Tennessee (UT) University Libraries. This article has been accepted for inclusion in Journal of Applied Sport Management by an authorized editor. For more information, please visit https://trace.tennessee.edu/jasm. 


\title{
Who Are Our Fans: \\ An application of Principal Component-Cluster Technique Analysis to Market Segmentation of College Football Fans
}

\author{
Daniel Rascher \\ Mark S. Nagel \\ Kenneth Cortsen \\ Tiffany Richardson
}

\begin{abstract}
A 66-question online marketing survey of 2,800 football fans who had purchased tickets to a Division I, Power 5 (P5) university football game was conducted in order to understand the fan base and provide better services and targeted marketing. Principal Component Analysis was employed to combine responses from multiple questions about purchase behavior, on-site satisfaction, demographics, and other criteria. Subsequent market segmentation via cluster analysis indicated that $95 \%$ of the survey respondents could be categorized into one of five clusters. The identified fan perceptions and evaluations resulted in the P5 athletic department taking specific actions to improve targeted marketing activities and enhance game-day experiences, including improving the quality and diversity of food offerings, ensuring smoother ingress and egress, offering more precise ticket packages, and targeting groups through relevant marketing channels. The current research notes the importance of utilizing precision marketing efforts to target specific clusters and then providing appropriate tangible and intangible products and services to maximize initial sales, improve fan experience, and increase the likelihood of repeat purchases.
\end{abstract}

Keywords: cluster analysis; college football fans; marketing; sport business analytics

Daniel Rascher is a Professor at the University of San Francisco, California

Mark S. Nagel is a Professor at the University of South Carolina

Kenneth Cortsen is an Assistant Professor at University College of Northern Denmark

Tiffany Richardson is a Lecturer in the Albers School of Business and Economics at Seattle University

Please send correspondence to Daniel Rascher, rascher@usfca.edu 


\section{Introduction}

Understanding existing and potential customers is crucial to any organization's core goals and creates significant business value. In the spectator sport industry, successful organizations have consistently invested in studying who their customers are, whether they are those who purchase tickets to live events or those who consume through various media outlets. The implementation of advanced customer relationship management (CRM) systems over the past few decades has allowed sport organizations, including college athletic departments, to track their fans, observe fans' behaviors, and entice fans to increase their consumption habits through targeted marketing messages. Well-developed CRM systems are a key component of precision marketing activities that can adapt a sport organization's commercial direction to changing fan interests and behaviors (Jinga, 2016). To excel in today's vibrant sports marketplace, it is important to remain flexible and proactive rather than static and reactive.

In the college sport environment, and specifically Division I Power 5 (P5) football, tens of thousands of fans of varying backgrounds and interests attend games, and hundreds of thousands or even millions may consume content on traditional and digital media channels. In addition, these fans may purchase many types of licensed merchandise. In regard to on-site attendance, decisions such as implementing multi-tiered, variable, and dynamic pricing; creating fan zones to entertain patrons; developing halftime acts beyond the traditional student band performances; selecting on-site food and beverage choices; enhancing facility features such as restroom and merchandise areas; and improving facility ingress and egress have all been influenced by customer data. Ultimately, big-time college sporting events attract a diverse set of customers, necessitating the use of market segmentation to maximize the experience of each attendee. Moreover, because college athletic departments have multiple partners (e.g., sponsors, media), understanding their teams' fans allows them to maximize value for (and from) their sponsors and media partners. Thus, properly executed sport business analytics provide relevant information to handle and commercially exploit the diversity of a sport organization's fan base (Fried \& Mumcu, 2016; Green, 2018; Harrison \& Bukstein, 2016).

A survey of a P5 university's football program's fan base was conducted (generating over 2,800 responses) in order to better understand customer preferences and behaviors, create improved services, and better target marketing to these fans. Utilizing a principal component-cluster technique analysis in order to create market segments resulted in the identification of five such segments that represented just over $95 \%$ of the respondents. These consisted of "High-Income Critics," "Older Experiential Seekers," "Price-Sensitive Health-Conscious Fun-Seekers," "Single-Game, Middle-Income Critics," and "Core Football Fans." Their perceptions, demographics, and media use are explained in detail. Though all venues and events are unique, studying a P5 football program's fans can provide interesting and informative insights for sport marketers across a variety of environments, and the current methodology employed provided the P5 university's athletic department with extensive, actionable information that was utilized to enhance its on-site fans' experiences.

\section{Literature}

The general business and sport management literature extensively covers market segmentation and methods to enhance understanding of consumer motivation. In particular, fan behavior (Funk, 2017; Funk, Alexandris \& McDonald, 2016; Sutton, McDonald, Milne \& Cimperman, 1997; Wann, Melnick, Russell \& Pease, 2001) and market segmentation (Bartels, 1988; Weinstein, 1994; Wind \& Bell, 2008) has been identified as a critical area of sport marketing research. As noted by Mullin, Hardy \& Sutton (2014, p. 118), "good internal marketing data from ticket applications, membership inquiries, and similar sources often reveal especially important geo-demographic clusters of these consumers." However, though the idea of studying fan desires and behaviors may seem simplistic, the actual collection and analysis of data can be quite complex employing sophisticated and triangulated quantitative and qualitative methods. Scholars (Cortsen \& Rascher, 2018; Wind \& Bell, 2008) emphasize that the changes in the local, regional, national, and global business environments involving technology and data development create new demands for advanced business and research methods. The commercialized sport landscape requires sport organizations to understand and capitalize on shifting fan engagement behaviors. This may necessitate a hybrid sport marketing and branding emphasis (Cortsen, 2016) aligned with co-creation and co-branding and in sync with various fan segments to enhance an immersive fan experience (Pine \& Gilmore, 1999). This underscores the importance of the subject matter of this article in that sport organizations systematizing their marketing activities grounded in relevant research can stimulate interest among non-fans or spur additional spending among 
current fan segments (Fetchko, Roy, \& Clow, 2018; Kim, Yoo \& Pedersen, 2007). Previous sport management segmentation studies (Broughton, 2012; Stewart, Smith \& Nicholson, 2003) demonstrated that sport organizations can benefit from new research concerning how behavioral economics (Karg, Tamaddoni \& McDonald, 2021; Bar-Eli, Krumer \& Morguley, 2020) can assist in optimizing sport business revenue potential by linking cluster analysis to sports marketing. These methods can help to find new avenues to capitalize on fan engagement, often by improving the understanding of motivational consumer traits from various fan groups.

\section{Methods}

In order to better understand its on-site fans' perceptions and desires, a P5 university's athletic department sent a 66-question online survey in the off-season to 17,637 email addresses corresponding to previous ticket purchasers in its database. The initial solicitation yielded 2,817 completed surveys, 929 partially completed surveys (defined as more than $20 \%$ complete), and 412 incomplete surveys. This sample size (with corresponding response rate of nearly $16 \%$ ) is sufficient if it is representative (Folz, 1996, p. 52). Additionally, the number of valid email addresses was unknown. Respondents needed an average of over 15 minutes to complete the survey.

In order to determine whether the sample was representative of the population, comparisons were made between the population and the sample. The only information known about the population was its ticket-buying history (not its demographics or any other characteristics). It was estimated that approximately $53 \%$ of the population (email addresses in the database) purchased season tickets only, with the remainder having purchased single-game tickets or both single-game tickets and season tickets. Fifty-three percent (53\%) of the survey respondents self-identified as season-ticket-only purchasers; thus, at least on this criterion, the sample was representative of the population. Assuming a random sample, the sample size is statistically significant, with a 95\% confidence interval of less than $2 \%$ (Crompton, 1999).

In addition to determining descriptive statistics, cluster analysis was employed to better understand the data. Cluster analysis classifies observations, in this case those of fans of a P5 university's football team, into categories based on their similarity to each other and their differences from those of other groups (Kaufman \& Rousseeuw, 2005). Similarity is determined by the responses to individual questions (i.e., two respondents in the same age range, all else being equal, are deemed more similar than those in different age ranges; two respondents who rate the importance of ticket pricing in their purchase decision similarly would be considered similar along that dimension).

Given the survey had an extensive list of variables, before conducting a cluster analysis, researchers first utilized a Principal Component Analysis (PCA) to condense the many variables into a smaller number of category groups (Fabrigar \& Wegener, 2012). These categories included logistics and customer service, quality of the team, pre-game promotions, price sensitivity, concessions, merchandise, the band, scoreboard programming, and family activities, with satisfaction questions utilizing 5-pt Likert scales. The PCA helped decrease the number of variables that were correlated with each other. The factor-score results (composite variables) represent the original variables but allow for fewer dimensions and more orthogonality. Principal components extraction with varimax rotation was employed, after other rotations were analyzed, in order to simplify the interpretation of the factors.

This made the cluster analysis feasible in that there were a small enough number of variables in order to measure commonalities among the respondents. This combination of PCA and cluster analysis is essentially equivalent to the Factor-Cluster Technique (Grover \& Vriens, 2006), but the dimension-reducing step uses PCA instead of traditional exploratory or confirmatory factor analysis.

The cluster analysis involved a two-step procedure of the components from the PCA, along with demographic variables gender, age, and household income (Norušis, 2003). Because the actual and mean responses for a given variable use different units, it was important to standardize each variable (using the traditional standard normal of 0 mean and 1 standard deviation). Hierarchical cluster analysis of a random sample of observations was used (multiple times) to determine that five clusters fit the data, and then a k-means cluster analysis was employed. Data was screened for outliers, although none were present.

General Survey Results

\section{Results}

About three-fourths of the respondents were male, and $44 \%$ of the males were over age 55 . There were relatively more 
women (39\%) among the younger respondents (ages 18 to 24). The income distribution was more even, with 27\% reporting household incomes over $\$ 200,000$, but the next-highest grouping $(\$ 100,000$ to $\$ 124,999)$ represented only $16 \%$ of respondents. Those earning over $\$ 200,000$ were most likely to be between 35 and 54 years old. Almost $40 \%$ of those in that age group earned over $\$ 200,000$, which is relatively high compared to the median in the area of the university, and much higher than the median in the US.

In order to provide context for the results, at the time of the survey, the football program had recently experienced a level of success that was superior to what it had achieved in the immediate decades prior. This undoubtedly impacted the findings (Wann \& Branscombe, 1990). Thirty-nine percent (39\%) of respondents fell into two or more categories in terms of their relationship with the school, with the most common being alumni (50\%) and donors (22\%). This was also the most common combination; in fact, 719 of the 857 donors were also alumni. However, only $37 \%$ of alumni were also donors. Seven percent $(7 \%)$ of respondents had no direct relationship to the school. Over $10 \%$ of respondents were both alumni and family of alumni (and nearly two-thirds of those had donated to the school). About $62 \%$ of respondents were members of the school's athletic association (booster club), but donors need not be members of the booster club. Almost $70 \%$ of those over 55 years of age were also boosters, while only $40 \%$ of those under age 35 were booster club members. The "other" category was filled with parents/family of current students (about 3\%). This was not an option for the checkboxes in the survey. Also, "general fans" represented another 4\% (bringing "no direct relationship" to around 11\%).

As mentioned previously, 53\% of respondents purchased season tickets only. Over half of respondents purchased two season tickets, with another $28 \%$ purchasing four or more. Season-ticket buyers attended about 5.5 games per season (out of seven home games), while single-ticket buyers attended about 2.1. Seat purchasers who were eligible to purchase tickets in a young alumni section tended to be about 30 years old and to buy fewer than two season tickets. Similarly, over $30 \%$ of fans ages 25 to 34 bought one season ticket, while less than $10 \%$ of fans over 44 years of age bought a single season ticket. Younger fans and female fans tended to buy more single-game tickets (although the differences were not large).

Alumni, faculty, and staff tended to buy season tickets only (overwhelmingly), while donors purchased more combinations of season tickets and single-game tickets. Those with no relationship to the school purchased more single-game tickets than season tickets.

\section{Principal Component and Cluster Analysis}

Because the survey contained hundreds of variables (237 to be exact), statistically determining the interrelationships between them was nearly impossible due to multicollinearity. A key issue, among others, is that many of the variables will be correlated with each other, thus causing estimates of how one variable affects another to be biased and inconsistent. Standard methods to solve this problem include conducting a PCA that takes many of the variables and statistically reduces them to a smaller number that can be used for further analysis.

A PCA was performed to essentially combine some of the variables but retain their essence. Separate analyses were conducted on purchase decisions and satisfaction. The first analysis focused on the respondents' decision to purchase tickets and what primarily spurred that decision (17 possible reasons). Those variables resulted in four (4) final factors. Factor 1 was a variable that captured the importance of logistics and customer service (e.g., crowds, customer service, and transportation). Factor 2 focused on the importance of the quality of the team. Factor 3 identified ancillary items such as pre-game activities, promotional giveaways, and change in job/child status. Factor 4 emphasized price sensitivity and non-conference schedule. These factors explained $67 \%$ of the variation in the original variables, with a Kaiser-Meyer-Olkin test statistic of 0.84 , and an overall significance of 0.009 , which are both sufficient and significant.

A second PCA was performed on the merchandise, concessions, and in-game activities ratings questions (32 aspects). There was a single factor, Factor 1, which captured concessions. Similarly, Factor 2 captured merchandise. Factor 3 contained information about the band, dance team, and on-field recognition of athletes, teams, etc. Factor 4 pertained to the scoreboard (e.g., advertising and sponsorship activation activities). Finally, Factor 5 was a variable focused on the mascot and family activities. These factors explained $58 \%$ of the variation in the original variables, with a Kaiser-Meyer-Olkin test statistic of 0.82 , and an overall significance of 0.011 , which are both sufficient and significant.

Cluster analysis determines if the respondents fall into usable or definable customer segments whereby the members of a given segment have similar perceptions about their experience at a game at this P5 school or along other metrics. It creates different markets to target that might be based on demographics or psychographics, but these markets could also be based on perceptions or feelings about their experience. Once the different segments are understood, marketing strategies 
can be used to address each one.

The resulting nine factors, along with age, household income, and gender, were used to create market segments of similar respondents using the aforementioned cluster analysis. As shown in Table 1, the final five clusters exhibit strong variation across most of the categories. A closer look at the raw data and gender variable indicates that the third cluster is more likely to contain women than the other clusters (although the majority of respondents were men).

\section{Table 1}

Final Cluster Centers

\section{Cluster}

\begin{tabular}{lcrrrr} 
& $\mathbf{1}$ & $\mathbf{2}$ & $\mathbf{3}$ & $\mathbf{4}$ & $\mathbf{5}$ \\
\hline Gender & 1 & 1 & 1 & 1 & 1 \\
Age & 5 & 6 & 3 & 4 & 5 \\
Household Income & 8 & 3 & 2 & 5 & 7 \\
Logistics and Customer Service factor 1 & .583 & -.219 & -.221 & .453 & -.558 \\
Quality of Team factor 2 & -.066 & .013 & -.172 & -.121 & .277 \\
Pre-game Promotions, Job/Child Status factor 3 & .192 & -.147 & .352 & .379 & -.517 \\
Price Sensitivity, Schedule Quality factor 4 & -.180 & .015 & .118 & .020 & .060 \\
Concessions factor 1 & -.463 & .263 & .414 & -.356 & .187 \\
Merchandise factor 2 & -.196 & .210 & -.230 & -.288 & .299 \\
Band factor 3 & -.109 & .205 & -.057 & -.479 & .221 \\
Scoreboard factor 4 & .099 & -.151 & .154 & .362 & -.246 \\
Mascot and Family Activities factor 5 & .022 & .108 & -.047 & -.129 & -.017 \\
\hline
\end{tabular}

The first cluster (High-Income Critics) consists of respondents who were less than satisfied regarding concessions and merchandise, which influenced their decision to purchase tickets. Additionally, they were very discerning regarding crowds, customer service, and transportation. Family status (job or child or relocation) also was an important factor in their decision to purchase tickets. These were very-high-income-earning respondents who are upper middle aged and likely to be alumni. This group is most likely willing to contribute to the booster club to get better seats. They rate their overall experience on the athletic department's website the lowest, as well as their overall experience at a game of this P5 school the lowest. They represent just over $20 \%$ of the sample.

The second cluster (Older Experiential Seekers) are older, low-to-middle-income earners who are influenced positively by concessions, merchandise, and the school band, but the scoreboard events (including advertising) and field announcer are not appealing. Customer service, transportation, and crowds are not important in their decision to buy tickets, nor is their family status (job, child, etc.). They are more likely to have no direct relationship to the school than those in other groups, except those in the fourth cluster. They also tend not to use social media. These respondents comprise about $28 \%$ of the sample.

The third cluster (Price-Sensitive, Health-Conscious Fun-Seekers) consisted of younger, lower-income earners who were more likely to be women than those in the other clusters (although there were still more men in this group). They were also more likely to purchase single-game tickets relative to the other groups. This group was overwhelmingly likely to include young alumni. They cared most about concessions (healthy options in particular) and promotional giveaways, and they were more price sensitive than those in the other clusters. Team quality and customer service were less important. They enjoyed the video scoreboard (including the sponsorship activations involving racing and pets) more than others. They were the least likely to listen to local radio stations but the most likely to use social media. They were not interested in receiving marketing materials from the school. This was a smaller group, totaling roughly $14 \%$ of the sample. 
Table 2

Summary of Clusters

\begin{tabular}{|c|c|}
\hline Cluster Name & Primary Characteristics \\
\hline High-Income Critics & 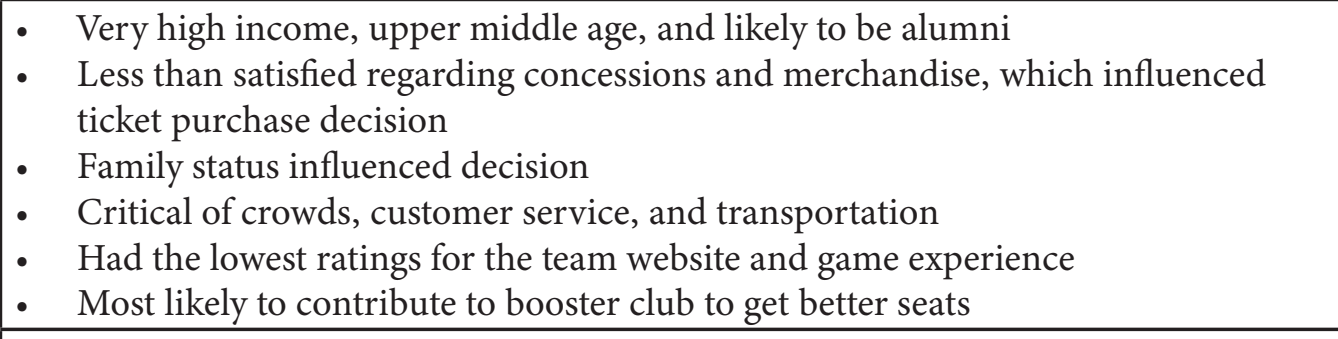 \\
\hline Older Experiential Seekers & $\begin{array}{l}\text { - Older, low-to-middle income } \\
\text { - Like concessions, merchandise, and band } \\
\text { - Dislike scoreboard activities, advertising, and field announcer } \\
\text { - Customer service, transportation, crowds, and family status are not important in } \\
\text { ticket purchase } \\
\text { - Less likely to have a direct relation to school } \\
\text { - Do not use social media }\end{array}$ \\
\hline $\begin{array}{l}\text { Price Sensitive, Health-Con- } \\
\text { scious Fun Seekers }\end{array}$ & $\begin{array}{l}\text { - Younger, lower income, and more likely to be women (relative to other groups) } \\
\text { - More likely to purchase single-game tickets } \\
\text { - } \quad \text { Young alumni } \\
\text { - } \quad \text { Teare about concessions (healthy options) and promotions, and are price sensitive } \\
\text { - Enjoy scoreboard activities } \\
\text { - Least likely to listen to local public radio and major local sports radio, but most } \\
\text { - } \quad \text { likely to use social media } \\
\text { - Do not want to receive marketing materials from school }\end{array}$ \\
\hline $\begin{array}{l}\text { Single Game, Middle-Income } \\
\text { Critics }\end{array}$ & 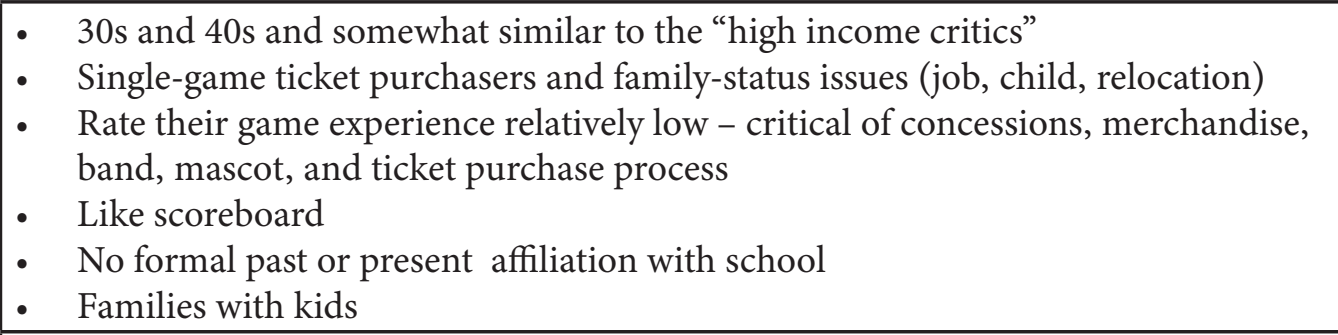 \\
\hline Core Football Fans & $\begin{array}{l}\text { - Middle-age, mid-to-high incomes, and fewest women } \\
\text { - Team quality and consuming football games are main concerns } \\
\text { - } \quad \text { Buy the most season tickets and attend the most games } \\
\text { - } \text { Most likely to be booster club members, listen to local public radio, and not use } \\
\text { - } \quad \text { For those who are not booster club members, most interested in donating money } \\
\text { to get better seats } \\
\text { - Ticket buying process is perceived as fine } \\
\text { - } \quad \text { Ho not care about logistics, customer service, promotions, etc. } \\
\text { - Not interested in scoreboard activities } \\
\text { - Want to eat well, buy team gear, and listen to the band }\end{array}$ \\
\hline
\end{tabular}


The fourth cluster (Single-Game, Middle-Income Critics) were in their thirties and forties and were similar to the high-income critics (the first cluster), but they were more likely to purchase single-game tickets and have family-status issues that affected their purchase decisions. Like the first cluster, they rated their overall experience at a game of this P5 school relatively low. They were also critical of concessions, merchandise, and even the school's band, but they did like scoreboard features more than other clusters. They were the least satisfied with the ticket-purchasing process and options. They were relatively less likely to be alumni and the most likely group to have no affiliation with the school. They were also relatively critical of the school's mascot. Based on ticket purchase habits, these were likely primarily families with kids. They were least likely to want to receive marketing materials from the school. This group consisted of $16 \%$ of the sample.

The fifth and final cluster (Core Football Fans) cared primarily about the quality of the team, and the football product was their main concern. They did not care about logistics, customer service, promotions, etc. They rated their overall experience at a game of the P5 school the highest. They do not find the scoreboard activities of interest, but they do want to eat well, buy school merchandise, and listen to the band. These are primarily middle-age core football fans with relatively high incomes. They bought the most season tickets, attended the most games, were most likely to be members of the booster club, and were most satisfied with the ticket-buying options and process. They rated their overall experience on the athletic department's website the highest. Those who were not members of the booster club were more interested in donating to the booster club to get better seating than other groups. They are most likely to listen to local radio stations and least likely to use social media. This cluster consisted of about $20 \%$ of the respondents and had the fewest women.

\section{Discussion and Implications}

The use of sport business analytics, particularly with the implementation of advanced statistics, has become an important element of many successful sport marketing activities. Through appropriate analytics, sport marketers can enhance precision marketing and other targeted and retargeted commercialization activities, which will add economic value. Ultimately, brand equity is maximized when organizations create appropriate products and services and present them properly to specific segments and target groups.

In the present case study, identified clusters helped the P5 football program create and emphasize specific elements of the on-site experience to the fans who would most likely react positively to those messages. At the conclusion of the research study, a number of ideas were proposed, and some were implemented in the following season(s). Core Football Fans who purchased season tickets were sent messages and materials emphasizing the players and coaching staff. In addition, these fans were targeted with opportunities (assuming there was sufficient financial support through donations and ticket purchases) to attend exclusive events (pre-season, pre-game, etc.) where they could meet players and coaches and gain insights about the upcoming season and/or game. Conversely, High-Income Critics were informed about off-season stadium facility enhancements and potential seat upgrades and were presented with opportunities to upgrade their parking arrangements. Though the age of the facility made exclusive access points difficult to implement, opportunities to create more rapid ingress and egress were explored, and seats that might offer more "room" were presented. Older Experiential Seekers were sent marketing messages emphasizing the event experience and opportunities to be around other fans in a fun environment. Price Sensitive, Health-Conscious Fun Seekers were targeted with messages focusing on single-game attendance, with a number of "affordable" price opportunities presented. Given the age and vast size of the football team's facility, it was possible to identify less desirable seats that could be discounted to attract fans attending on a budget. In addition, some "healthier" food options were made available, many bathrooms were upgraded, and the athletic department discussed implementing special "young alumni" games that would offer pre-game activities designed to let fans socialize. It was recommended that Single Game, Middle-Income Critics should be targeted with messages emphasizing the affordability of tickets. Given that many in this cluster had families, the messages were not only to emphasize affordability for some games and seat locations, but also to include free pre-game and in-game opportunities to participate in family-friendly activities, particularly at certain games played during the afternoon rather than the evening.

In the present case study and throughout the sport marketing world, the use of sophisticated CRM software programs enables targeted messages to be sent before and during games. An important consideration is tying the specific marketing message to the individuals within each cluster that will maximize customer behavior, but to also acknowledge that during live events, each potential marketing cluster exhibits different behaviors, but all fans attend in an interconnected marketplace. For instance, in the present research, Core Football Fans often displayed their passion visibly and vocally, which 
frequently created a vitalizing fan sound. Even though some other cluster groups may not value the quality of the on-field product as much as other factors, their experience is positively affected by the "die-hard" fans maintaining a high level of passion and emotion during the games. This displayed passion can create greater interest by other fan groups since the event becomes (or appears to become) much more important and worthy of attending. Within this interconnected marketplace, a variety of revenue sources can be enhanced by the proper targeting of individual fan characteristics, as higher attendance typically leads to greater commercial value creation through not only greater ticket revenues, but also enhanced concessions, parking, licensed merchandise, sponsorship, and media rights revenues. Though there will always be some overlap across the customer base (e.g., everyone sees and hears the scoreboard, uses the restrooms, and has to enter and exit the facility regardless of their rating of importance), the more that sport organizations can emphasize the aspects of the facility and event that are of greatest importance to each customer while also remembering the interconnectedness of those clusters, the greater the opportunity for marketing and financial success.

\section{References}

Bar-Eli, M., Krumer, A., \& Morgulev, E. (2020, December). Ask not what economics can do for sports - Ask what sports can do for economics. Journal of Behavioral and Experimental Economics, 89.

Bartels, R. (1988). The history of marketing thought (3rd ed.). Columbus, OH: Publishing Horizons.

Broughton, D. (2012, July 23). Research segments fans by lifestyle, not sport. Sports Business Journal. Retrieved from https://www.sportsbusinessjournal.com/Journal/Issues/2012/07/23/Research-and-Ratings/Team-Epic.aspx

Cortsen, K. (2016). Strategic sport branding at the personal, product and organizational level. Doctoral Dissertation. Aarhus: Aarhus University.

Cortsen, K., \& Rascher, D. (2018). The application of sports technology and sports data for commercial purposes. In D. A. Marinho \& H. P. Neiva (Eds.), The use of technology in sport-emerging challenges (pp. 47-83). IntechOpen.

Crompton, J. L. (1999). Measuring the economic impact of visitors to sports tournaments and special events. Ashburn, VA: National Recreation and Park Association.

Fabrigar, L. R., \& Wegener, D. T. (2012). Exploratory factor analysis. New York, NY:Oxford University Press, Inc.

Fetchko, M. J., Roy, D. P., \& Clow, K. E. (2018). Sports marketing. New York, NY: Routledge.

Folz, D. H. (1996). Survey research for public administration. Los Angeles, CA: Sage Publications, Inc.

Fried, G., \& Mumcu, C. (Eds.). (2016). Sport analytics: A data-driven approach to sport business and management. Philadelphia, PA: Taylor \& Francis.

Funk, D. C., Alexandris, K., \& McDonald, H. (2016). Sport consumer behaviour: Marketing strategies. New York: Routledge.

Funk, D. C. (2017). Introducing a sport experience design (SX) framework for sport consumer behaviour research. Sport Management Review, 20(2), 145-158.

Green, F. (2018). Winning with data: CRM and analytics for the business of sports. New York: Routledge.

Grover, R., \& Vriens, D. M. (2006). The handbook of marketing research: Uses, misuses, and future advances. Washington, DC: SAGE Publications.

Hamilton, L. C. (2009). Statistics with STATA (8th ed.). London, England: Cengage Learning.

Harrison, C. K., \& Bukstein, S. (Eds.). (2016). Sport business analytics: Using data to increase revenue and improve operational efficiency. Boca Raton, FL: CRC Press.

Karg, A., Tamaddoni, A., McDonald, H., \& Ewing, M. (2021). Predicting season ticket holder retention using rich behavioral data. Journal of Sport Management. Advance online publication. https://doi.org/10.1123/jsm.2020-0190

Kaufman, L. \& Rousseeuw, P. J. (2005). Finding groups in data: An introduction to cluster analysis. Hoboken, NJ: Wiley-Interscience.

Kim, S., Yoo, E., \& Pedersen, P. M. (2007). Market segmentation in the K-League: an analysis of spectators of the Korean Professional Soccer League. International Journal of Sports Marketing and Sponsorship, 8(2), 26-43.

Mullin, B. J., Hardy, S., \& Sutton, W. (2014). Sport marketing (4th ed.). Champaign, IL: Human Kinetics.

Norušis, M. J. (2003). SPSS 12.0 Statistical Procedures Companion. London, England: Prentice Hall. 
Pine, B. J., Pine, J., \& Gilmore, J. H. (1999). The experience economy: Work is theatre \& every business a stage. Boston, MA: Harvard Business Press.

Stewart, B., Smith, A. C., \& Nicholson, M. (2003). Sport consumer typologies. Sport Marketing Quarterly, 12(4), 206216.

Sutton, W. A., McDonald, M. A., Milne, G. R., \& Cimperman, J. (1997). Creating and fostering fan identification in professional sports. Sport Marketing Quarterly, 6, 15-22.

Wann, D. L., \& Branscombe, N. R. (1990). Die-hard and fair-weather fans: Effects of identification on BIRGing and CORFing tendencies. Journal of Sport and Social Issues, 14(2), 103-117.

Wann, D. L., Melnick, M. J., Russell, G. W., \& Pease, D. G. (2001). Sport fans: The psychology and social impact of spectators. New York, NY: Routledge.

Weinstein, A. T. (1994). Market segmentation: Using demographics, psychographics and other niche marketing techniques to predict customer behavior. Nashville, TN: Probus Publishing Co.

Wind, Y. \& Bell, D. (2008). Market segmentation, in Baker, M. \& Hart, S. (Eds.), The marketing book (pp. 222-244). Oxford: Elsevier. 